\title{
Land-use Change and Its Impact on Production and Consumption of Strawberry in Tapalpa, Jalisco, Mexico
}

\author{
Fatima Ezzahra Housni ${ }^{1{ }^{*},}$, Virginia Gabriela Aguilera Cervantes ${ }^{2}$, Mariana Lares-Michel ${ }^{1}$, Norma Helen Juárez ${ }^{1}$, \\ María del Carmen Barragán Carmona ${ }^{2}$, Rosa María Michel Nava ${ }^{3}$ \\ ${ }^{1}$ Research Center in Territory and Rurality, University Center of the South, University of Guadalajara \\ ${ }^{2}$ Research Center in Food Behavior and Nutrition, University Center of the South, University of Guadalajara \\ ${ }^{3}$ National Technology of Mexico, Campus Ciudad Guzmán \\ *Corresponding author: fatima.housni@cusur.udg.mx
}

\begin{abstract}
In recent years, the municipality of Tapalpa, Jalisco, has suffered a gradual deterioration of natural resources (water, forest, soil). There has been a growth of population and an increase in tourism activities that do not consider natural resources, types of landscape or their socio-economic implications. One of the most relevant changes in the municipality, in addition to deforestation, is the change of land use by another type of agriculture. Change and the availability of new foods can lead to change the consumption habits of the community. The aim of this paper was to evaluate the impact of agribusiness strawberry with respect to changes in the environment, and its impact on the feeding process, since this depends largely food security. For this purpose, a multi-temporal analysis of Landsat ETM+ satellite images from 2000 and 2017 respectively was carried out in the municipality of Tapalpa, Jalisco. Likewise, a Food Consumption Frequency Questionnaire (FCFC) was applied, taking a sample of 264 adults distributed between 18 and 60 years of age, to evaluate strawberry consumption in the municipality. The results showed an evolution of landscape fragmentation at all levels with a reduction in the percentage of hectares of forest land use and a significant increase in hectares of protected agriculture. Regarding consumption, the results indicated that $67 \%$ of the sample consumes strawberry and that the amount depends on the harvest period.
\end{abstract}

Keywords: land-use change, protected agriculture, multi-temporal analysis, strawberry consumption, Tapalpa

Cite This Article: Fatima Ezzahra Housni, Virginia Gabriela Aguilera Cervantes, Mariana Lares-Michel, Norma Helen Juárez, María del Carmen Barragán Carmona, and Rosa María Michel Nava, "Land-use Change and Its Impact on Production and Consumption of Strawberry in Tapalpa, Jalisco, Mexico." Journal of Food Security, vol. 5, no. 3 (2017): 58-65. doi: 10.12691/jfs-5-3-1.

\section{Introduction}

The municipality of Tapalpa has suffered a gradual deterioration of the natural resources (water, forest, soil). This situation is explained by the population growth and the increase of tourist activities in the region. But mainly because of an accelerated change of land use from natural to others (residential, agricultural and livestock) [1]. The municipality has also been involved in a process of agricultural modernization, where new productive techniques have begun to be introduced, such as protected agriculture, where its main production is destined for export crops, such as strawberry, a fruit with little antecedent in the town $[2,3]$. This type of agriculture aims to maximize crop yields without paying attention to the conservation of the natural resources (soil, water, atmosphere, biodiversity) on which it is based. Moreover, such intensive agriculture has resulted in serious environmental problems such as contamination of soils, groundwater, erosion and salinization of soils, including the reduction of biodiversity [4]. Según los datos publicados por el Instituto Nacional de Salud Pública, la cuarta parte de los mexicanos no tiene suficiente acceso a la alimentación [5]. In addition, the commercial approach of these new agricultural systems dissociates agriculture from the food needs of the population, focusing only on export. This alarming situation does not comply with the pillars of food security.

This, understood as the guarantee for the population to have the food in sufficient quantity, easy access and to meet their basic needs [6].

\section{Material and Method}

\subsection{Study Area}

The area studied in this research corresponded to the municipality of Tapalpa, located southeast of the state of Jalisco, Mexico. At the coordinates from $19^{\circ} 36^{\prime} 49^{\prime \prime}$ to $20^{\circ}$ $05^{\prime} 54^{\prime \prime}$ north latitude and from $103^{\circ} 36^{\prime} 20^{\prime \prime}$ to $103^{\circ} 54^{\prime}$ $00^{\prime \prime}$ west longitude. Figure 1 shows its delimitation.

\subsection{Procedure}

The present work was carried out by means of two investigations: The first one corresponded to applied research by means of analysis of satellite images; the 
second was descriptive and transverse cut. At this stage a mixed method was used where a food consumption frequency questionnaire, validates in Mexico, was applied with some qualitative questions.

\subsubsection{Multitemporal Analysis}

In the first stage, a multitemporal analysis was carried out using the Landsat ETM + digital image processing (Enchanced Thematic Mapper Plus) to identify the change of land use in the municipality of Tapalpa Jalisco between 2000 and 2017. It was sought to generate information from The land-uses on both dates and obtain data on the change during that 17-year period. This treatment was divided in three phases: a) Preprocessing, b) Processing and c) Postprocessing. All this analysis was performed with ArcGis 10.3 software. It should be mentioned that this work included fieldwork to verify the data generated.

\subsubsection{Evaluation of Frequency and Quantity of Strawberry Consumption}

The second stage consisted in the collection of data on the consumption of the main fruit produced under greenhouse in the municipality of Tapalpa: the strawberry.

\subsubsection{Participants}

For the evaluation of strawberry consumption in the municipality of Tapalpa, the sample size was calculated for a finite and well-known population corresponding to the total adult population in the municipality of Tapalpa, Jalisco. A 95\% confidence interval and 5\% error margin were considered. The sample to be studied was 264 participants. They were used as inclusion criteria to have an age between 18 and 60 years and to have lived in the municipality for at least one year.

\subsubsection{Instrument}

A structured survey, made up of a Frequency Questionnaire on Food Consumption (CFCA), validated for the Mexican population and adapted according to the study was used as instrument [7]. Participants had to indicate the frequency of strawberry consumption, using one of the following categories: never, once a month, 2 to 3 times a month, 1 time a week, 2 to 4 times a week, 5 to 6 Times a week, once a day, 2 to 3 times a day, 4 to 5 times a day or 6 or more times a day. Consumption quantities were evaluated by ranges: 1 to 5 pieces, 6 to 10 pieces, 11 to 16 pieces, 17 to 22 pieces, 23 to 28 pieces, 29 to 34 Pieces and 35 or more pieces. The above according to the unit of measure of ration used in the Mexican Equivalent Food System (SMAE) [8]. Likewise, questions were included within the survey concerning the reasons why the fruit is ingested or not, in addition to questioning the participant if he / she knows the quality of the strawberry that consumes. It should be mentioned that before the start of the survey, the question of the current place of residence and the subject's age was questioned in order to exclude participants who did not meet the inclusion criteria of the study. The name, address or telephone number of the participant was not requested because it is irrelevant to the investigation and for the protection of the subject's identity. The data collection was carried out in the municipal head of Tapalpa as well as in the town of Ataco.

\subsubsection{Statistic Analysis}

The information obtained was transferred to a database in the software Excel 2016, to later analyze statistically the data with the software STATA / SE V12. First, we calculated the distribution of subjects according to their current consumption and during their childhood, as well as their frequency and quantity of current consumption. Afterwards a descriptive analysis of the information regarding the amount of strawberry consumption, in grams, was carried out. The established ranges were estimated and the mean, standard deviation, minimum value and maximum value of the data in grams were calculated. The reasons for consumption or not consumption were included according to the distribution of subjects who expressed similar reasons. Finally, the referred quality of the strawberry that the participants ingest was graphed by frequency of subjects.
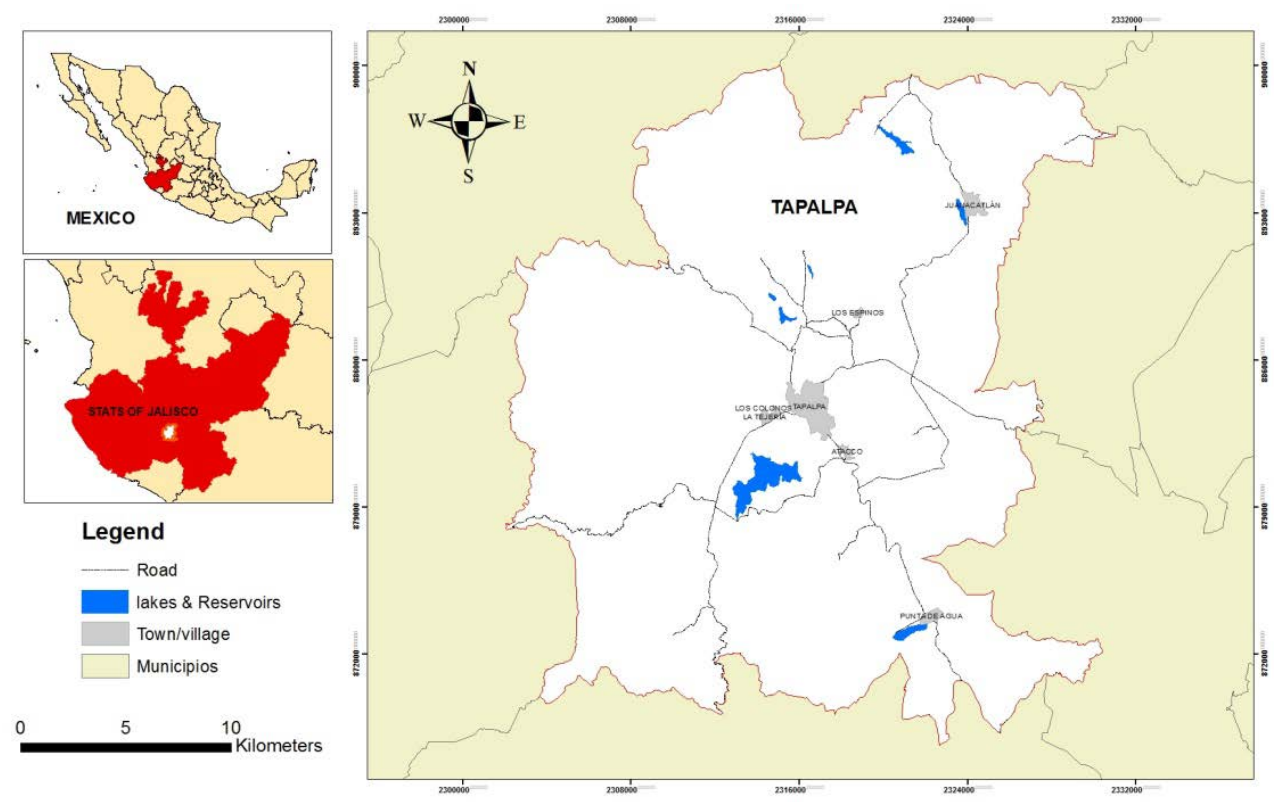

Figure 1. Study area 


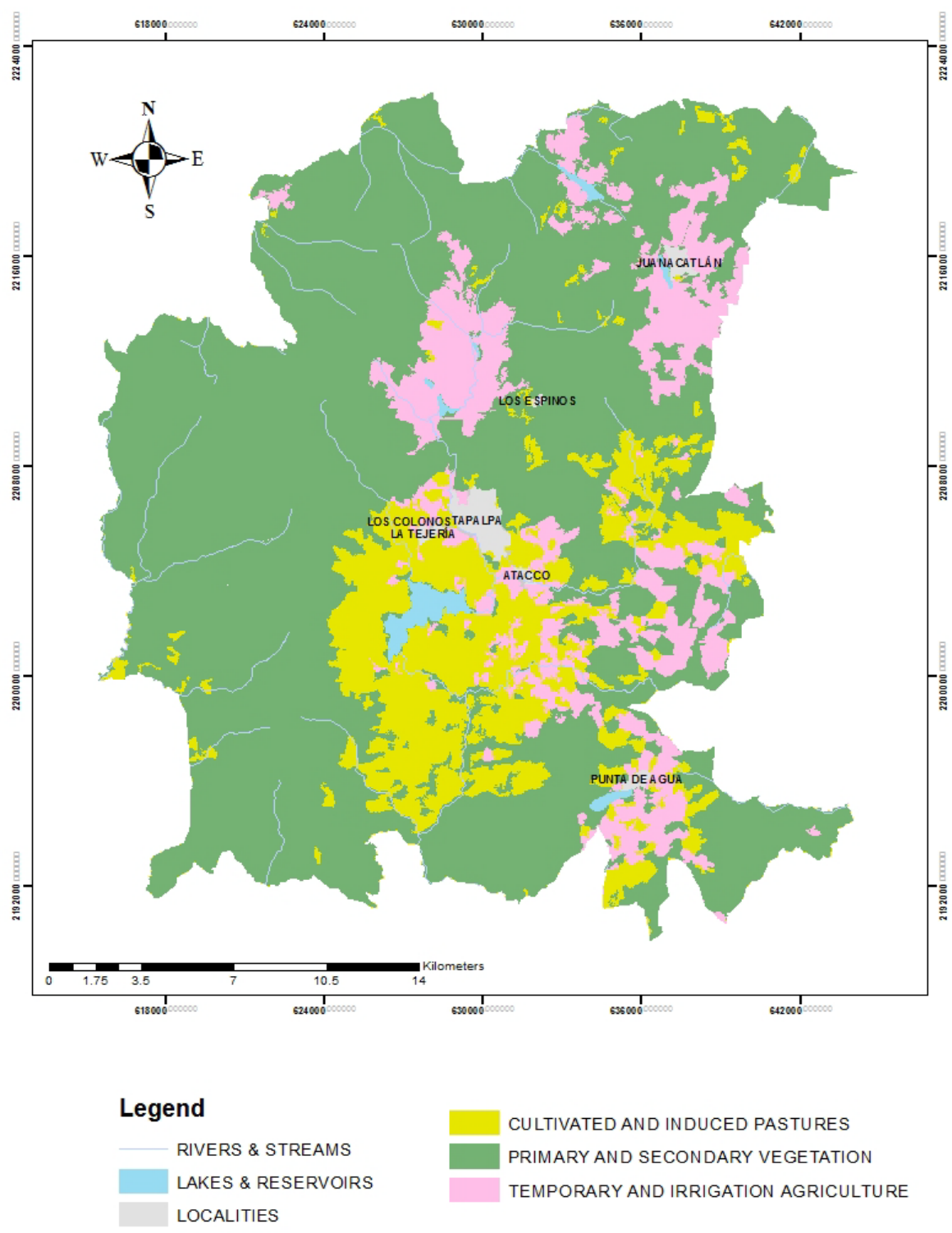

Figure 2. Land-use of the municipality of Tapalpa of the year 2000 (Own elaboration)

\section{Results}

\subsection{Change of land-use in Tapalpa}

In Figure 2 it is possible to observe the distribution of the vegetation of the municipality of Tapalpa, Jalisco in the year 2000 .

In pink it is possible to appreciate those hectares that in the year 2000 were covered with agriculture of temporary of annual cycle. The yellow colors refer to the areas covered at that time by grassland or pasture-induced vegetation. The different shades of green express the hectares that were covered with vegetation. Primary vegetation in the case of darker green and secondary vegetation slightly lighter green. The opaque green color shows areas with no apparent vegetation. The color blue refers to the body of water present in the municipality and finally in gray color you can see the hectares that correspond to the urban area. As can be seen, the municipality was mainly covered by primary vegetation, however, also a significant proportion of pastures is observed, in addition, temporary agriculture was the only type of agriculture present in the municipality. In numbers,
Table 1 shows the area in hectares and the percentage corresponding to the different types of vegetation in the municipality of Tapalpa. Of the 58,200 hectares that the municipality of Tapalpa has, the main land use is forest, since more than $74 \%$ is covered with primary and secondary vegetation of forest and jungle. With a smaller percentage, almost $11 \%$ of the total area of the municipality was occupied by rainfed agriculture and irrigation. The pasture represented $13.77 \%$ of the total area of the municipality and the urban area barely represented $0.76 \%$ of the total with only 445 hectares.

Table 1. Area of land-use in the year 2000

\begin{tabular}{|l|c|c|}
\hline \multirow{2}{*}{ Land-use } & \multicolumn{2}{|c|}{ Surface } \\
\cline { 2 - 3 } & has & $\%$ \\
\hline Temporary and irrigation agriculture & 6208.896 & 10.66 \\
\hline Lakes \& reservoirs & 407 & 0.72 \\
\hline Cultivated and induced pastures & 8017.634 & 13.77 \\
\hline Primary and secondary vegetation & 43121.47 & 74.09 \\
\hline Localities & 445 & 0.76 \\
\hline Totally & 58200 & 100 \\
\hline
\end{tabular}




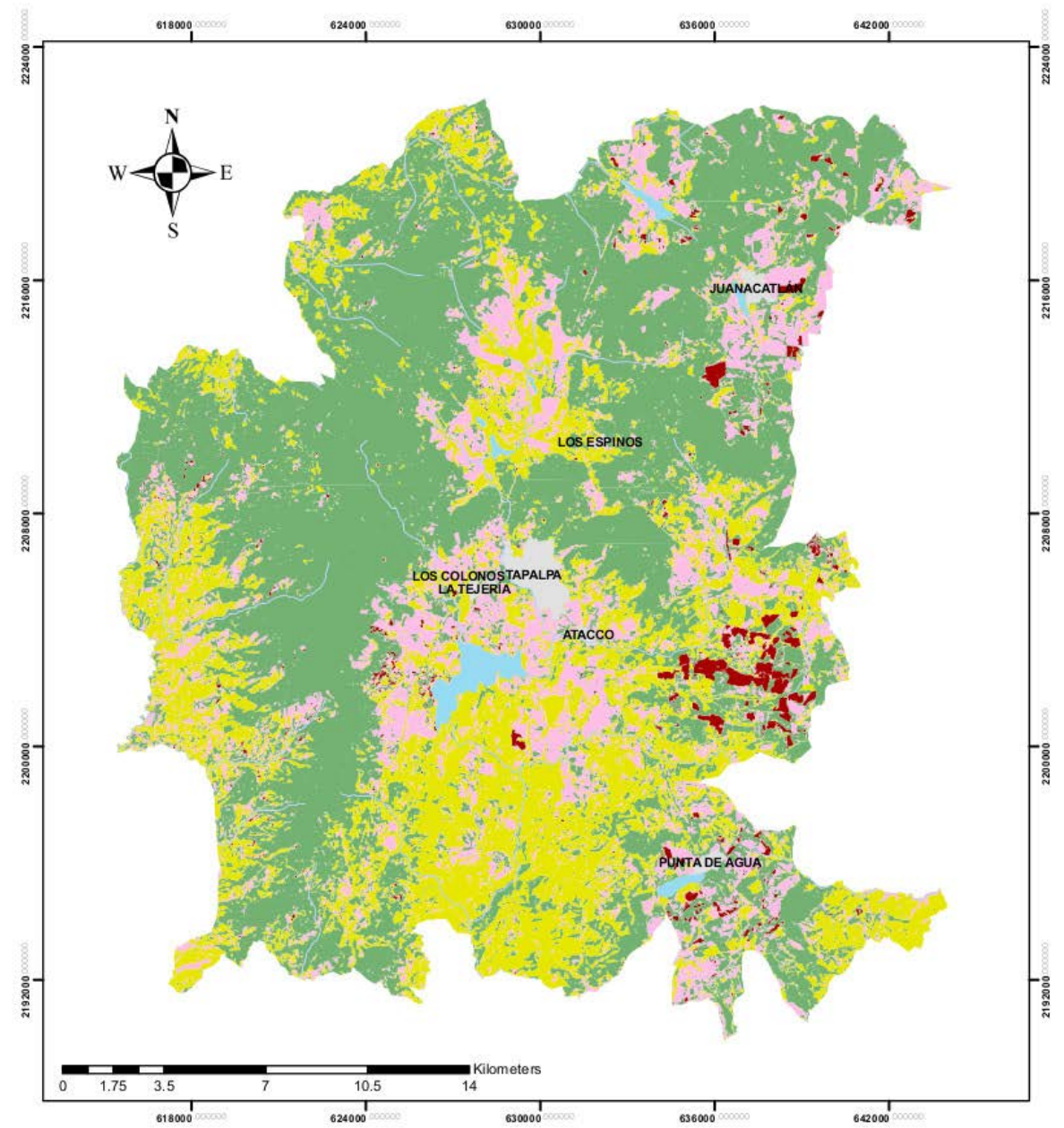

Legend

RIVERS \& STREAMS

LAKES \& RESERVOIRS

LOCALITIES
CULTIVATED AND INDUCED PASTURES

PRIMARY AND SECONDARY VEGETATION

TEMPORARY AND IRRIGATION AGRICULTURE

GREENHOUSE AGRICULTURE

Figure 3. Land-use of the municipality of Tapalpa of the year 2017 (Own elaboration)

Figure 3 shows the vegetation that was identified in the year 2017 in the municipality. At first glance it is possible to identify a decrease in primary and secondary vegetation, because of covering 74.09\% in the year 2000, in 2017 barely represents $56.73 \%$ of the total. At the same time, temporary and irrigated agriculture increased from 10.66\% in the year 2000 to $15.73 \%$ in 2017 . The same happened with the grasslands, where there was also an increase, going from $13.77 \%$ to $24.39 \%$. The urban area remained below $1 \%$, covering only 520 hectares. Table 2 shows the exact amounts in hectares as well as the percentages of the municipality's vegetation in the same year.

\subsection{Strawberry Consumption in Tapalpa}

Table 3 shows the distribution of the population surveyed according to their sex, current consumption and during their childhood and their frequency and amount of current strawberry consumption. The total population surveyed corresponded to 264 subjects, of whom 67\% were women and $33 \%$ were men. Of the population surveyed about $83 \%$ reported not having consumed strawberry during their childhood. With respect to the subjects who said to eat strawberry currently in a habitual way, sporadically or only in season it is observed that $39.77 \%$ of the sample consumes strawberry and $9.09 \%$ consumes it only in season. However, $46.21 \%$ of the sample does not usually consume it and $4.93 \%$ never consume it. That is to say that the fruit is not part of the daily diet of almost half of the sample population.

Table 2. Area of land-use in the year 2017

\begin{tabular}{|c|c|c|}
\hline \multirow{2}{*}{ Land-use } & \multicolumn{2}{|c|}{ Surface } \\
\cline { 2 - 3 } & has & $\%$ \\
\hline Temporary and irrigation agriculture & 9152.07 & 5.73 \\
\hline Lakes \& reservoirs & 407 & 0.72 \\
\hline Cultivated and induced pastures & 14192.22 & 24.39 \\
\hline Primary and secondary vegetation & 33026.61 & 56.74 \\
\hline Localities & 520 & 0.89 \\
\hline Greenhouse agriculture & 902.1 & 1.55 \\
\hline Totally & 58200 & 100 \\
\hline
\end{tabular}


The same table shows the distribution of subjects according to their frequency of strawberry consumption. As can be observed, most subjects ingested strawberry occasionally (61.36\%), as it was identified that 15 subjects consume strawberry at least once a month, 99 of the people consume it 1 to 3 times a month and 48 people surveyed consume strawberry once a week. On the other hand, 54 subjects ingest it 2 to 4 times a week and 15 subjects once a day. Few people consume it 5 to 6 times a week, 2 to 3 times a day, 4 to 5 times a day or 6 or more times a day. Overall, 22 people have the habit of ingesting strawberry with these frequencies, or $8.33 \%$. As already mentioned, of all the subjects surveyed, only 13 mentioned never to consume it.

Likewise, the distribution of the subjects surveyed according to the quantity in grams of strawberries consumed is appreciated. It can be identified that $25.38 \%$ of the people surveyed consume on average 102 grams of strawberry, $21.21 \%$ consume 36 grams; $18.94 \%$ of the sample consumes168 grams of the fruit, and 13 people do not consume any amount of strawberries. The rest of the sample consume more than 234 grams, an amount that is within the ration that establishes the Mexican System of Equivalent Foods (SMAE) [8].

Table 3. Distribution of the population by sex, consumption during childhood and current frequency and amount of consumption

\begin{tabular}{|c|c|c|}
\hline & \multicolumn{2}{|c|}{ subjects } \\
\hline & $\mathrm{n}$ & $\%$ \\
\hline Sex & 264 & 100 \\
\hline Female & 177 & 67 \\
\hline Male & 87 & 33 \\
\hline Consumption during childhood & 264 & 100 \\
\hline yes & 45 & 17.05 \\
\hline Not & 219 & 82.95 \\
\hline Current consumption & 264 & 100 \\
\hline Current consumption & 105 & 39.77 \\
\hline Sporadic consumption & 122 & 46.21 \\
\hline Consumption only in season & 24 & 9.09 \\
\hline Never consumes & 13 & 4.93 \\
\hline Frequency of consumption & 264 & 100 \\
\hline Never & 13 & 4.92 \\
\hline Less than one time per month & 15 & 5.68 \\
\hline One to three times a month & 99 & 37.5 \\
\hline once a week & 48 & 18.18 \\
\hline Two to four times a week & 54 & 20.45 \\
\hline Five to six times a week & 6 & 2.27 \\
\hline once a day & 15 & 5.69 \\
\hline One to three times a day & 11 & 4.17 \\
\hline Four to five times a day & 2 & 0.76 \\
\hline Six times a day or more & 1 & 0.38 \\
\hline Amount of consumption & 264 & 100 \\
\hline 0 pieces ( 0 grams) & 13 & 4.92 \\
\hline 1 to 5 pieces (36 grams) & 56 & 21.21 \\
\hline 6 to 11 pieces (102 grams) & 67 & 25.38 \\
\hline 12 to 16 pieces (168 grams) & 50 & 18.94 \\
\hline 17 to 22 pieces (234 grams) & 38 & 14.39 \\
\hline 23 to 28 pieces (306 grams) & 17 & 6.44 \\
\hline 29 to 34 pieces (378 grams) & 5 & 1.89 \\
\hline 35 or more pieces (483 or more grams) & 18 & 6.82 \\
\hline
\end{tabular}

Table 4. Statistical analysis of consumption

\begin{tabular}{|c|c|c|c|c|c|}
\hline Variable & $\mathbf{n}$ & Average & Standard deviation & Minimum & Maximum \\
\hline Grams & 264 & 158.81 & 124.98 & 0 & 483 \\
\hline
\end{tabular}

Table 4 presents a statistical analysis of the amount of strawberry consumption in the population evaluated. It is possible to appreciate that the average consumption of the population of Tapalpa, is smaller to 159 grams. The minimum consumption referred was 0 grams and the maximum of 483 grams. A standard deviation of 124.9803 was obtained.

With respect to the reasons why the persons evaluated said to consume or not strawberry, Table 5 shows these reasons of ingestion. As for consumption reasons, he emphasized the availability of the fruit, as a determinant factor for its consumption, that is to say that $36.25 \%$ of strawberry consumers ingest it only when it is available and for sale in the locality, mainly in season. On the other hand, $34.66 \%$ of the population surveyed said they consume the fruit only because they like the taste, texture or any characteristic of the fruit. It is important to note that among respondents, $10.75 \%$ of strawberry consumers reported being workers in a greenhouse in the municipality or said to have a friend or relative who works in said establishments, for which strawberries are given to them for consumption . On the other hand, $11.55 \%$ said they consume strawberry because of their nutritional properties. The rest of the population reported consuming it only sometimes, due to an economic impossibility or due to lack of availability. On the other hand, the reasons why people who said never eat strawberry (13 subjects) do not eat it because they do not like the taste of the fruit, however, were also identified people who said not to consume strawberry because they consider that strawberries are contaminated with chemical pesticides. Similarly, a portion of people not consuming strawberry, said not to ingest it because it is very expensive.

Table 5. Distribution of the population according to their reasons for consumption or non-consumption of strawberries

\begin{tabular}{|l|c|c|}
\hline \multirow{2}{*}{} & \multicolumn{2}{|c|}{ Subjects } \\
\cline { 2 - 3 } & $\mathrm{n}$ & $\%$ \\
\hline Consumption reasons & 251 & 100 \\
\hline Availability of fruit & 91 & 36.25 \\
\hline Likes taste, texture or characteristics & 87 & 34.66 \\
\hline Due to its nutritional properties & 29 & 11.55 \\
\hline They give you the fruit for working in greenhouses & 27 & 10.76 \\
\hline Only consumes it sometimes because of lack of availability & 9 & 3.59 \\
\hline Only consumes it sometimes because it is expensive & 8 & 3.19 \\
\hline Reasons for non-consumption & 13 & 100 \\
\hline He does not like the strawberry & 5 & 38.46 \\
\hline Why the fruit is contaminated with pesticides & 3 & 23.08 \\
\hline Because it is expensive & 2 & 15.38 \\
\hline Because it is not available & 2 & 15.38 \\
\hline Does not know & 1 & 7.70 \\
\hline
\end{tabular}

Finally, Figure 4 shows the results on the knowledge that has the population surveyed with respect to the quality of the strawberry that they ingest. $57 \%$ of the sample expressed that the strawberry they consume is of 
first quality, organic and very good; 24\% said they did not know the quality of the strawberry they eat while $15 \%$ said they were sure that the strawberry they consume is of "second quality" and is not suitable for export. Only 5\% said that it is of third quality and that it may be contaminated.

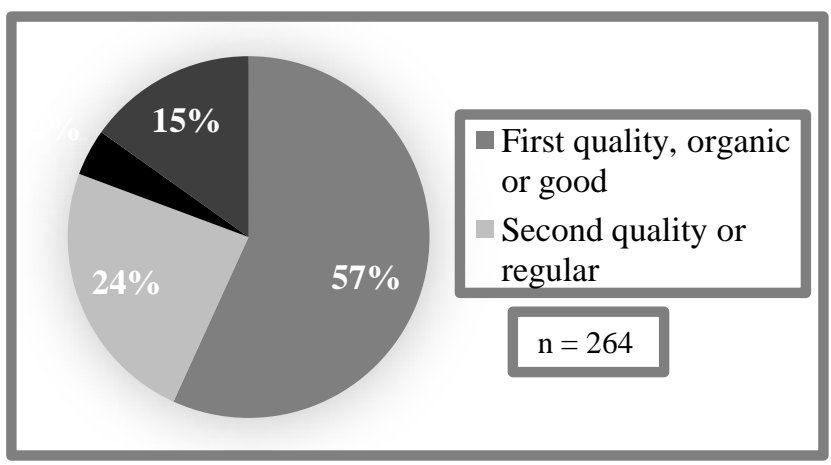

Figure 4. Rawberry quality according to consumers in the Municipality

\section{Discussion}

In this research we have seen transformations of forest vegetation, such as forests and forests, to another type of land use, between 2000 and 2017 in more than $17 \%$ of the total area of the municipality. This means that more than $17 \%$ of deforestation is observed in the entire municipality of Tapalpa. This transformation is so significant that it must be studied in more detail to measure its effects on the loss of biodiversity. Forest ecosystems are very relevant for biodiversity such as mesquite, mangrove, vegetation of coastal dunes, tulle, among others.

There was a 5\% increase in temporary and irrigated agriculture, which clearly shows a trend towards forest degradation. The present analysis demonstrated a very clear trend of forest fragmentation, while forests face a process of degradation. Table 6 shows these changes in the evaluated years.

The fragmentation of natural habitats is an almost universal and irreversible process, and the understanding of their ecological and genetic effects will allow, in the not so distant future, to design strategies for the conservation of biodiversity. An increase from $13.77 \%$ to $24.39 \%$ in pasture, indicates a not very encouraging trend in the use and conservation of the natural heritage of Tapalpa, given that the municipality depends on its resources to conserve its main economic activity, which corresponds to the commerce derived from tourism. According to information from INEGI's National Statistical Directory of Economic Units (DENUE), in 2015 the municipality had 818 economic units and its distribution by sectors reveals a predominance of economic units dedicated to commerce, being these $45.2 \%$ of the total. However, agriculture contributes only $0.4 \%$ of the total [9].

Protected agriculture accounted for only 902.1 hectares in 2017, that is, less than $1 \%$ of the total area of the municipality compared to other land uses in Tapalpa. However, more than $90 \%$ of its production is destined for export [9] and is not for local consumption. This situation is detrimental to the population of the municipality, since to sustain or increase production, necessary to maintain commercial alliances abroad, renewable natural resources such as water are used. This leads the population to place themselves in a degree of food vulnerability.

Before this disturbing scenario, in the second stage of the research a strawberry consumption frequency questionnaire was carried out, the main product of protected agriculture in the municipality, from which interesting data were identified. First, the fact that more than $82 \%$ of the population said they had not consumed strawberry during their childhood, allowed to identify a parallel transition with respect to production-consumption. That is, that 16 years ago, because there was no local strawberry cultivation, the population did not ingest it. However, when questioning consumption, frequency and amount of current intake, a consumption was found, which, although not daily, exceeded the referred intake during childhood. It is important to note that, in spite of this, the strawberry is not currently a staple food nor indispensable for the population of Tapalpa. However, in OEIDRUS data from Jalisco (2016), its production has increased from 0 tons in 2001, to generate 9,240 tons in 2015 (Figure 5) [3]. These figures are consistent with the increase observed in the results of this study, where in 2000 protected agriculture was not present in the municipality, whereas in 2016 it is. The same as in the case of consumption.

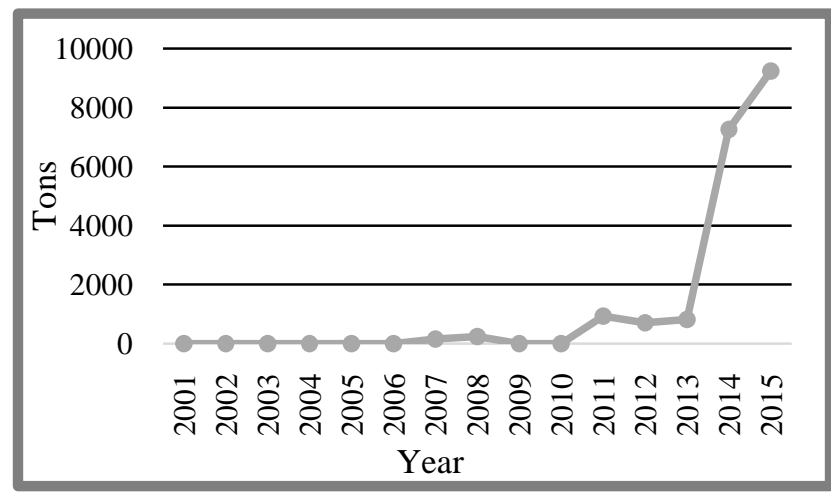

Figure 5. Strawberry production in Tapalpa from 2001 to 2015. Source: Elaborated with data of OEIDRUS Jalisco (2016)

Table 6. Soil surface according to use and variation of change between 2000 and 2017 in Tapalpa, Jalisco

\begin{tabular}{|c|c|c|c|c|c|}
\hline \multirow{2}{*}{ Land-use } & \multicolumn{2}{|c|}{ Year 2000} & \multicolumn{2}{|c|}{ Year 2017} & \multirow{2}{*}{$\begin{array}{c}\text { Variation } \\
\%\end{array}$} \\
\hline & has & $\%$ & has & $\%$ & \\
\hline Temporary and irrigation agriculture & 6208.896 & 10.66 & 9152.07 & 15.73 & +5.07 \\
\hline Lakes \& reservoirs & 407 & 0.72 & 407 & 0.72 & 0 \\
\hline Cultivated and induced pastures & 8017.634 & 13.77 & 14192.22 & 24.39 & +10.62 \\
\hline Primary and secondary vegetation & 43121.47 & 74.09 & 33026.61 & 56.74 & -17.35 \\
\hline Localities & 445 & 0.76 & 520 & 0.89 & +0.13 \\
\hline Greenhouse agriculture & 0 & 0 & 902.1 & 1.55 & +1.55 \\
\hline Totally & 58200 & 100 & 58200 & 100 & \\
\hline
\end{tabular}


Strawberry is a fruit with multiple health benefits [11]. However, Tapalpa has become one of the main exporters of the fruit and its population, according to the results of this study, hardly includes it in their daily diet. The main reason why respondents said they ingest this red fruit was due to their availability, which is a conditioning factor for their intake to be carried out, as stated by authors such as Bourges (2004) and The World Organization Of the United Nations Food and Agriculture Organization (FAO, 2011 [6,12]. However, because only $10 \%$ of production is destined for consumption by the population, the food security of this fruit is infringed [10]. Another important aspect is that the consumption of $10.76 \%$ depends on whether the fruit is given to them or not, since several people said that this fruit is expensive. However, this data allows identifying that more than 27 people are linked to field work under greenhouse, this activity being the source of employment of a considerable number of subjects. With regard to strawberry intake, only $29.54 \%$ of strawberry consumers ingested representative amounts according to the SMAE, which forms the basis of current dietary guidelines in Mexico [8,13].

Finally, FAO states that in order to ensure food security, in addition to physical, social and economic access to sufficient and nutritious food, these should be safe. The latter concept is understood as a food whose habitual consumption does not imply health risks because it is free of pathogenic micro-organisms, toxins, and contaminants and is consumed in moderation [14]. However, the use of agrochemicals in contemporary agriculture has been associated with low quality food and harmful to health [15]. When questioning the participants if they knew the quality of the strawberry they ingest, worrisome $24 \%$ said they did not know the quality and $15 \%$ and $4 \%$ acknowledged to eat strawberries that are considered of second or third quality respectively. However, one of the reasons why some people do not ingest strawberries was because they said that they are contaminated with agrochemicals. In this sense, further studies on chemical residues in this product would be necessary.

\section{Conclusion}

Although the strawberry is not a food of daily consumption nor is it considered basic for the population where it is produced, and that the production of foods of basic consumption like corn and wheat are less and less present in the municipality [3], it seems that it is not a problem that occupies the thoughts of the current politicians. The state is betting more and more on this new type of economic dealings, where food production is focused on the trade and not on the food security of the population. In fact, according to FIRCO in 2009 the government had an investment of more than 6 million pesos to support intensive production in strawberry macrotunel in Tapalpa, which led to increase strawberry production regardless of the detrimental effects that this entails to the environment. In this work it is clearly observed that the new tendencies of agriculture used in the municipality of Tapalpa have harmed the environment [2]. Deforestation is the most marked change in land use in the last 17 years. In addition to the scarcity of renewable resources such as water, Tapalpa's food security and selfsufficiency expectations are not encouraging. It is known that the human being is not exempt from the presence of famines, so there are elements that could prevent them, the first being the generation of agricultural production according to the needs of the population [16]. However, the production of strawberry under greenhouse in Tapalpa removes space and resources to the basic crops for the population.

\section{Acknowledgements}

Authors would like to acknowledge the great support offered by University Center of the South of The University of Guadalajara and the Research and Postgraduate Coordination for financial support to project No. SAC/CI/031/16 extended to this study.

\section{References}

[1] López, J. P., Montoya, B. R., Brindis, C. R., Sánchez-Monteón, A. L., Elia Cruz-Crespo, E. C., Juárez R. C. R., Alejo, S. A. G. and Balois, M. "Estructuras utilizadas en la agricultura protegida", Revista fuentes, 3(8). 21-27. 2011.

[2] Fideicomiso de Riesgo Compartido (FIRCO) Secretaría de Agricultura, Ganadería, Desarrollo Rural, Pesca y Alimentación (SAGARPA). Proyecto Estratégico de Agricultura Protegida (PROAP) Padrón de Beneficiarios (información preliminar). 2009. Available:

http://www.firco.gob.mx/transparencia/FraccionXI/Padr\%C3\%B3 n\%20Beneficiarios\%20PROAP\%20septiembre\%202009.pdf.

[3] Oficina Estatal de Información para el Desarrollo Rural Sustentable (OEIDRUS) Delegación Estatal de la Secretaria de Agricultura, Ganadería, Desarrollo Rural, Pesca y Alimentación (SAGARPA) del estado de Jalisco. Anuarios estadísticos. 2016. Available:

http://www.oeidrus-jalisco.gob.mx/agricultura/anuarios/index.php? idcurrent=2\&nivel=MUN

[4] Housni, F. E., Macías Macías, A., Magaña González, C. R., Bracamontes del Toro, H. And Najine, A. "Cambio de uso de suelo por los invernaderos en el municipio de Zapotlán el Grande, Jalisco, México: Un análisis multitemporal”, Ingeniantes, 2(1), 40-44. 2015.

[5] Gutiérrez JP, Rivera-Dommarco J, Shamah-Levy T, VillalpandoHernández S, Franco A, Cuevas-Nasu L, et al. Encuesta Nacional de Salud y Nutrición 2012. Resultados nacionales. Cuernavaca, México: Instituto Nacional de Salud Pública, 2012.

[6] Organización Mundial de las Naciones Unidas para la Alimentación y la Agricultura (FAO). (2011). Una introducción a los conceptos básicos de la seguridad alimentaria. En FAO (Eds.), La seguridad alimentaria: información para la toma de decisiones. Guía Práctica. Available: http://www.fao.org/docrep/014/al936s/al936s00.pdf.

[7] Macedo-Ojeda, G., Vizmanos-Lamotte, B., Márquez-Sandoval, Y. F., Rodríguez-Rocha, N. P., López-Uriarte, P. J., and FernándezBallart, J. D. "Validation of a semi-quantitative food frequency questionnaire to assess food groups and nutrient intake”, Nutrición Hospitalaria, 28(6), 2212-2220. 2013.

[8] Pérez, L. A. B., Palacios, G. B., Castro, B. A. L., and Flores, G. I. Sistema Mexicano de Alimentos Equivalentes (Documento Técnico, Cuarta Edición). Fomento de Nutrición y Salud, Instituto Nacional de Ciencias Médicas Salvador Suvián y Ogali. México, 2014.

[9] Instituto de Información Estadística y Geografía. Tapalpa. Diagnóstico del Municipio. Septiembre 2016. Available: http://iieg.gob.mx/contenido/Municipios/Tapalpa.pdf.

[10] Asociación Mexicana de Horticultura Protegida (AMHPAC). Jalisco exporta más del $90 \%$ de su producción de "berries". Notimex. January 2015. Available: http://www.amhpac.org/es/index.php/noticias/547-jalisco-exportamas-del-90-de-su-produccion-de-berries. 
[11] Seeram, N. P. (2007). Strawberry phytochemicals and human health: a review. UCLA Center for Human Nutrition, David Geffen School of Medicine, University of California. Available: https://www.researchgate.net/publication/228983423_Strawberry_ phytochemicals_and_human_health_a_review.

[12] Bourges, R. H. Abasto y consumo de alimentos: una perspectiva nutriológica. In Del Valle, R. M. D. C. (Ed.), El desarrollo agrícola y rural del tercer mundo en el contexto de la mundialización. Universidad Nacional Autónoma De México, Instituto de Investigaciones Económicas, México, 2004, 433-451.

[13] Secretaría de Salud. (2010). Guía de alimentos para la población mexicana. Available: http://www.imss.gob.mx/sites/all/statics/salud/guia-alimentos.pdf.

[14] Suárez, S. M. D. C. "Significado externo de "alimentación correcta” en México”, Salud colectiva, 12(4), 575-588. 2016.

[15] Agência Nacional de Vigilância Sanitária (Anvisa). "Resíduos de agrotóxicos em alimentos”. Revista de Saúde Pública, 40(2), 361-363. 2006.

[16] Housni, F. E., Aguilera, C. V. C., Bracamontes, D. H., Macías, M. A., Llanes, C. C. and Magaña, G. C. El cambio climático y la alimentación. In A. López-Espinoza y A. G. Martínez Moreno (Eds.), La educación en alimentación y nutrición, McGraw Hill, Mexico, 2016, 267-279. 